\title{
Cloning and Sequencing Full Length of Canine Brca2 and Rad51 cDNA
}

\author{
Kazuhiko OCHIAI ${ }^{1)}$, Masami MORIMATSU ${ }^{1 *}$, Nobuyuki TOMIZAWA ${ }^{2)}$ and Bunei SYUTO $^{1)}$ \\ ${ }^{1)}$ Laboratories of Veterinary Physiology and ${ }^{2)}$ Veterinary Surgery, Faculty of Agriculture, Iwate University, Morioka 020-8550, Japan
}

(Received 23 April 2001/Accepted 25 June 2001)

ABSTRACT. Mammary tumors are the most common neoplasm in female dogs, Canis canis, and in women. Mutations in human Brca2 confer an increased risk of female breast cancer. Previous studies have shown that the Brca2 tumor suppressor protein interacts with the recombinational repair protein Rad51. We cloned the full-length cDNA of the canine homologues of Brca2 and Rad51 to obtain a basis for studying their relationship with susceptibility to mammary tumors. The canine Brca2 and Rad51 cDNAs are 11 and $1.5 \mathrm{~kb}$ long, encoding 3,471 and 339 amino acids, respectively. The amino acid sequence of canine Brca2 showed 68\% homology with the human protein, and $58 \%$ homology with a murine protein. There were highly conserved regions in the C-terminus of all three proteins, where the Rad51 interacting domain and putative nuclear localization signals are located. Comparing with the partial genomic sequence previously reported, we found possible nuclear polymorphisms in exon 11, some of which result in amino acid substitutions. On the other hand, canine Rad51 protein had extremely high homology (99\%) to the human and murine proteins. Expression of both Brca2 and Rad51 was detected in the mammary gland, suggesting that these two genes interact in the canine mammary gland.

KEY WORDS: Brca2, genetic instability, mammary tumor, Rad51, tumor suppressor gene.

J. Vet. Med. Sci. 63(10): 1103-1108, 2001

In female canines and women, mammary tumors are the most frequent neoplasm $[5,15]$. They constitute $40 \%$ of all tumors in female dogs, which is three times the incidence of mammary tumors in humans $[4,12,20]$. No other animal species has such high provability of onset of mammary tumors.

The treatment of advanced breast cancer is often futile and disfiguring, making early detection a high priority in management of the disease. Six years ago, the human breast cancer susceptibility gene Brca2 was identified [22, 23]. After sequencing the full-length cDNA, many reports described mutational analyses of the gene in families and in primary tumors [7, 9, 19]. The Brca2 gene consists of 27 exons, which encode an 11- to 12-kb transcript. The Brca2 cDNA sequence, which predicts a 3,418 amino acid protein, shows no obvious homology to any other protein [3, 22]. The tumor suppressor function of Brca2 appears to be associated with its biochemical interaction with $\operatorname{Rad} 51$ protein $[11,17,21]$. Rad51 plays a central role in mediating homologous recombination events, and can promote strandexchange in vitro $[13,14]$. A recent report suggested that alterations in the Rad51 gene are involved in the development of hereditary mammary tumors [8].

To understand the role of tumor-related genes in canine mammary gland tumors, we describe the cloning and sequencing of canine Brca2 and Rad51 cDNA as a first step toward the functional analysis of these genes. We compared the canine sequences with those of other species, and studied the pattern of gene expression.

\footnotetext{
* Correspondence to: Morimatsu, M., Laboratory of Veterinary Physiology, Faculty of Agriculture, Iwate University, Morioka 020-8550, Japan.
}

\section{MATERIALS AND METHODS}

cDNA cloning of canine Brca2 and Rad51: The polymerase chain reaction (PCR) was performed using the primers shown in Fig. 1A. For Brca2, the primer sequences corresponding to exon 11 were designed from the sequence reported by Bignell et al. (GenBank accession number: Z75664), while those for other regions were designed from reported human (GenBank accession number: NM_000059) and murine (GenBank accession number: U65594) sequences. Rad51 primers were designed using human (GenBank accession number: D14134) and murine (GenBank accession number: D13803) sequences.

Total RNA was extracted from the testis of a 3-year-old male beagle by the guanidine-isothiocyanate method [2]. The total RNA $(4 \mu \mathrm{g})$ was denatured at $70^{\circ} \mathrm{C}$ for $10 \mathrm{~min}$, cooled immediately, and reverse transcribed using 200 units of M-MLV reverse transcriptase (Gibco-BRL, Gaithersburg, MD, U.S.A), $25 \mathrm{pmol}$ of random primer, and $10 \mathrm{nmol}$ dNTPs in a total volume of $20 \mu \mathrm{l}$ at $37^{\circ} \mathrm{C}$ for $50 \mathrm{~min}$. After heating at $75^{\circ} \mathrm{C}$ for $15 \mathrm{~min}$, PCR amplification was performed with 2.5 units of Extensor Long PCR Enzyme Mix (AB Gene, Surrey, U.K.) or KOD Plus (Toyobo, Osaka, Japan), $1.5 \mathrm{mM} \mathrm{MgCl} 2,20 \mathrm{nmol}$ of dNTPs, and 20 pmol of primers. PCR was conducted for 30 cycles, each consisting of denaturation at $94^{\circ} \mathrm{C}$ for $30 \mathrm{sec}$, annealing at $53^{\circ} \mathrm{C}$ for 30 sec, and extension at $68^{\circ} \mathrm{C}$ for $2.5 \mathrm{~min}$. PCR amplification of the 5' and 3' cDNA ends of canine Brca2 and canine Rad51 was performed with the RACE System (Gibco-BRL, Gaithersburg, MD, U.S.A), and 10 pmol of the target-specific primers shown in Fig. 1A. PCR was conducted for 30 cycles, each consisting of denaturation at $94^{\circ} \mathrm{C}$ for $30 \mathrm{sec}$, annealing at $55^{\circ} \mathrm{C}$, and extension at $72^{\circ} \mathrm{C}$ for $5 \mathrm{~min}$. The PCR products were subcloned into pGEM-T Easy Vector.

cDNA sequencing and analysis: The sequences were 


\begin{tabular}{|c|c|c|c|c|}
\hline Clone number & Primer & Nucleotides & Sequence $\left(5^{\prime}\right.$ to $\left.3^{\prime}\right)$ & Product size \\
\hline \multicolumn{5}{|l|}{ Canine Brca2 } \\
\hline No. 1 & Reverse & $453-472$ & AGGAGATTGTTGGTATATTG & 473 \\
\hline \multirow[t]{2}{*}{ No. 2} & Forward & $287-306$ & ATAAGCCTCAATTGGTTTGA & 2092 \\
\hline & Reverse & $2359-2378$ & TTGCGGCCGCGCAGGGATGACAGACAATCA & \\
\hline \multirow[t]{2}{*}{ No. 3} & Forward & $2176-2196$ & TTGCGGCCGCTGTTTACAGAATGACTCAGA & 2266 \\
\hline & Reverse & $4422-4441$ & AGCTTTCATAACTTCCAAAC & \\
\hline \multirow[t]{2}{*}{ No. 4} & Forward & $4273-4292$ & TGATTCCAGTAAAAATGATA & 2396 \\
\hline & Reverse & $6649-6668$ & TGACGTCGACAGTGTTCTGGGGTTCTCTTA & \\
\hline \multirow[t]{2}{*}{ No. 5} & Forward & $6459-6478$ & TTGCGGCCGCATTTACTATCATCTGCTTTC & 1809 \\
\hline & Reverse & $8246-8267$ & TTAGGCATCTATTAGCAAATTC & \\
\hline \multirow[t]{2}{*}{ No. 6} & Forward & $8112-8133$ & GAAAAGAAGAATTTTATAGGGC & 2117 \\
\hline & Reverse & $10211-10228$ & TGGCTGAAATGCCTTCTG & \\
\hline No. 7 & Forward & $9974-9993$ & ATGTCTTCTCCCAATAATGA & 985 \\
\hline \multicolumn{5}{|l|}{ Canine Rad51 } \\
\hline No. 8 & Reverse & $473-492$ & TTTGTCAGCTTTGGCTTCAC & 493 \\
\hline \multirow[t]{2}{*}{ No. 9} & Forward & $274-295$ & ATGGCWATGCARATGCAGCTTG & 1020 \\
\hline & Reverse & $1274-1293$ & TCAGTCTTTGGCATCKCCCA & \\
\hline No. 10 & Forward & $1173-1192$ & GTATCTGAGGAAAGGAAGAG & 341 \\
\hline
\end{tabular}

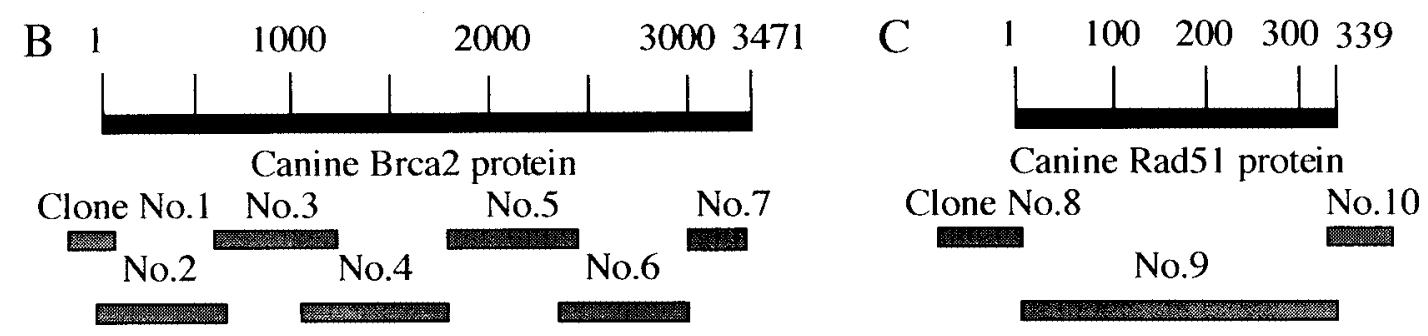

Fig. 1. Cloning canine Brca2 (A) and Rad51 (B) cDNA. (A) Profiles of cloning primers and PCR products of canine Brca2 and Rad51. For RACE clones (clones 1, 7, 8 and 10) only specific primers are shown. Primers containing the restriction site are: No. 2 reverse, No. 3 forward, No. 4 reverse, and No. 5 forward. (B) Seven cDNA clones were amplified from canine testis RNA. Shown here are the seven clones representing the full-length canine Brca2 cDNA. The upper bar shows the canine Brca2 protein (3,471 amino acids). (C) Canine Rad51 cDNA was amplified in the same way. The three clones represent the full-length canine Rad51 cDNA. The upper bar shows the canine Rad51 protein (339 amino acids).

determined for at least three independent clones using Big Dye Terminator Cycle sequencing reagents and an Applied Biosystem Sequencer 310 (Perkin, Elmer, Tokyo, Japan). The complete nucleotide sequences and the predicted amino acid sequences were analyzed and compared with the GenBank databases using the personal computer-based sequence-analyzing software Clustal X 1.81 and GENETYX-MAC (Software Development, Co., Tokyo, Japan).

The tissue distribution of canine Brca2 and Rad51: RTreaction was performed for RNA extracted from testis, ovary, mammary gland, spleen, skeletal muscle, and brain.
PCR amplification was performed with the following primers (the nucleotides in parentheses indicate mixtures): canine Brca2, 5'-CCGCTCGAGTCACCAATTCATTGTCATTTTTGTG-3' and 5'-CAGAGCCACACACAGCTCAA-3'; canine Rad51, 5'-ATGGC(AT)ATGCA(AG)ATG CAGCTTG-3' and 5'-TCAGTCTTTGGCATC(GT)CC CA-3'. RT-PCR was performed as described for cDNA cloning, except that $1 \mu \mathrm{g}$ of RNA was used. The PCR products were electrophoresed on $1 \%$ agarose gels and stained with ethidium bromide. Glyceraldehyde-phosphate dehydrogenase (GPDH) was used as a control. 
A

1 MPVGCKERPTFFEIFKTRCNQADLGPISLNWFEELSLEAPPYNSEPTEESGYKISYEPNLFKTPQRKPYNQLASTPIVFREPIYQQSPLKELDKYRLDSG 101 KDITDSKHKSCCTMKSKMDRANDVTSPPLNSYLSESPVLRCTHVTPQREKSWVCGSLFHTPRLMRGQTPKRISESLGAEVDSDMSWSSSLATPPTLSSRI 201 SESIGAEVDSDMSWSSSLTVLIVRDEEVSAAVFPNDTTAIFKSCF SNHDESLKKNDRF IPCGPGKENKNQREAKSOSLGNSFGKVNSTKDHFVKSTPNVL 301 EGEVHEKVLDVSEEEDSFSLCVPKYKTRNLQKIKTSKTRKNIFNETKTSECEEAKKQMKENKHSLVSEMEPNDSHPLDWNVTHEKPFGNGTDK ISKE IVL 401 SSASGCSDLTLSSLNGAQMEKTPLLHTSYDQNNSEKDLI ITDKECTNFITLENSWPQISNVPKYSEKTLNEE IVVNKINEGQCLESHEDSVVSVKQAIYE 501 TTLIASPLQGIRKSIFRIRESPEGMSNAMFSNNMTNPNFKEPEASESGLEKHTICSQKEDSLCTSSIDDGSWPAT IKHTSVALKNLGLISSLKKKTKKF I 601 YVINDETSNQGLKTQKDQESRL INLSTQFEANAFEGPLTFTNADSGLLHSSS IKKNCLONDSBKPALSLTSSFGTILRKVSSNGASSPNNKI ISQDPDYK 701 EAK INKKKLESF ITTETDCLSSLOEKHWEDDAKKQRVSD IKKKVLPTVSHP PVPHSEVEGSDIHFQSPESFSFDCDNTSLLTPSSRDSPSSLVVMSRGKE 801 SYKISEKLKCKNHETGFKLTKNI PMEKNQD I HVLNADSKNAKC.TSTEKKH I TVASSSVKVQFNQNANLTTIQKDQRETTL ISK I TVNPNSEELFFDDENNF 901 VL.K ITNESNTPVLGNTKELHDSNLCCVRDSVPKNSTMVVCTDLDDKOTAKVS TMKDCYSSS IDDLTERNRSTIKQQL.KMTLDQDSKSD ITSDIVRKSNGN 1001 SDYMDNWARLSDPISNHSFENGFXTASNKEIKLSENNIRKSKOHFKDIEEHY PTNLACLE TVNTSSIESQKKPSKSHALDPQS INIISGFVQNSTYVSDS 1101 ESGHTAPPTLSLKQDFDSNRNLTPSQRAEITELSTILEESGSQFEFTQFRKPSHI I QKNPFEMPENQLTILNSTSKEWKDDDLHLTTNAPS ISQVDSKKS 1201 EGI IGGKOKFACLSRTSCNRSASGYSTDKNEVEFRGFYSARGTKUNVGSEALQKAKKLFSDLBNINEETSVEVDRSFSSSKYNDSVSMIQ IEDCNDKNLN 1301 ERNNRCRL IIQNN IEMTTDIFVEEY TESYRRNTENBGNQCTDAGRNTCNSESDGSDSSKNDTVY IHEEENGLPCIDQHNIDLKLF SQFMKEGNTQIKEGL 1401 SDLTCLEVMKAEETSHVTMSNKQQLTANTGQN IKDFDIFYLSFQTASRKNIRVSRESLNRARSLLNQKWTEEELNNFSDSINSELLPGID IKKTDISNHE 1501 VIENTERKDKI TKESDLIGTEN ILLILOQRPESK IKK IKESAVLGFHTASGKKIEITKESLDKVKNLFEEKEQDNSE ITNFSHRGAKMSKDREECKDGRE 1601 LACGTTEI TTTPE YEETHSSLEKKKLVSNEI AALRPRULSDNLYKQTENLK ISDHASQKVDVHENTEKETAKRPTMYTNQSTYSA IENSPLTFYTGHGRK 1701 ISUSEASLFEAKKWLREGEWDDQSERINAAKVNCLKE XPDDYVENPSCGNSSNSAITENDKNHLSEKQGSTYLSNSTMSNSYSYHPGFCHSSEVYNKSEY 1801 LSRSKIDNSGIEPVIKNIRERKNIGFSEIMS PGREADTDPQSVNED ICVEKLATWSSCKNKNTAIKVAISDSNKFNTIQRLNSDSNNSVPAYSTVNSKRV 1901 FVARQTKVTEGFTDNCSAVTKQNTKSKSDTCHAEIVADYPKALDDSEAIFPKSLGAIECSPSHKVF ADIQSEQTSQLNQSMSGLEKVSETPPCQINSKTS 2001 DRCELPRGKLFKSVSTTVACGIFSTASGRSVQVSDAAIOROREVF SKLEDSARQWF PEVSLKDNEEHSEKFTNEENTV IYTSQNLLSSAF SGFRTASGRQ 2101 VPVSESALCKVKGMLEEFNLIRTESCLQHSSTSRQDVSKMPPPSCIGKRTPEHSRNSKLDKACNKEFRLSSNCNNQSGSSENHHSIKVSPCPSQLKRDKP 2201 QLLVGSKGSLVENIHPLGKEQALPKNIKTEIGKAETFPNLPVKTNIEFCSTYSKDPENYFETETVE IAKAFMEDGELTDSELLSHAKHFVFTCONTKEMV 2301 LLNSRIGKRRGDALVSVGEPP IKRNLLNEFGRIIKNQETSLKASKSTPDGILKDRSLFMHHISLEPISCGPFRTTEERQE IQNPNFTAPGQEFLPKSHFY 2401 EHLASEKSSSNLSVSRQPFCMVPATGNEKRRHLIAPGKPVKVFVPPF KTKSHFHRDEQCISKNTKLEKNKONSKDIDELGSGDSEKNINDSGIHQL KKNN 2501 SNQAATI IFTKNEKEPLDLITNLQNARDIQDMRIKKKQRQH IFPQPGSLYLAKTSTLPRISLREAVEGRVPSACSHKQLYMYGVSKHCVKINSKNAESFQ 2601 FHAQDYFGKEGLWSGEGIQLPDGGWLIPSNDGKIGKEEFYRALCDTPGVDPNCISRVWVYNHYRWI IWKLAAMEFAF PKEFANRCLSPERVLLQLKYRCD 2701 VEIDKSRRSAIKKIMERDDTAAKTLVLCISEI ISSSADISETSSSKTSSVGTKKVGI IALTDGWYAI KAQLDPPLLALVKNGRLTVGQKITIHGAELVGS 2801 PDACTPLEAPESLMLKISANSTRPACWYTKLGFSPDPRPFPLPLSSLF SDGGNVGCVDVVVQRAYPIQWMERTPSGLCIFRNEREEEKEATKYAEIQQKK 2901 LEVLFNKIQAEFEKNDENITKQCIPSCALTRQQICALQDGAEL YEAVTNAPDPSDLEGYFSEEQLRALNNHRQMLNDKKQAQIOLEFKKAMESAEQGEQI 3001 LPRDVTTVWKLRI ISYRKKEKDSVTLSIWRPSPDLYSLLIEGKRYRI YHLAASQSKSKSGKANTQLTATKKTQYQQLPASDEILSQVYQPREPLYFNKLL 3101 DPDFQPPCSEVDI.IGFVVSVVKKIGLAPVVYLSDECHNLLAIKFWTDFNEDIIKPYTLIAASNLOWRPEAKSGIPTLFAGDFSRFSASPKEEHFQETFHK 3201 MKNTVENIGMFYNDAENKLVHIINANDPKLSTPTKDYASEPHTAQIVLGIGNKFLMSSPNNEMNYQSPLSLCKPKEKSVPIPGSTQMTSKSYCKEEKEMD 3301 DPKTCKRRRALDFLSRVPLPPSVSPICTFVSPAAQKAFQPPRSCGTKYETZMKKELNSPQMTPRKFNDLSLLESDSIADEELAMINTQALLLGSPGEHQI 3401 VSVSDSTRTAPTSSKDYLGLKRHSTAPGVRGPESPQACTRKREPRVQNTSDLKRTISETAEATNTKMTMNW*

B

1 MAMQMQLEANADTSVEEESFGPQPISRIEQCGINANDVKKLEEAGFHTVEAVAYAPKKELIS I KGISEAKADKILTEAAKLVPMGFTTATEFHQRRSEI I 101 QITTGSKELDKLLQGGIETGSITEMFGEFRTGKTQICH'TLAVTCQLPIDRGGGEGKAMY IDTEGTFRPERLLAVAERYGLSGSDVLDNVAYARGFNTDHO 201 TQLLYQASAMMVESRYALL IVDSATALYRTDYSGRGELSARQMHL.ARFLRMLLRLADEFGVAVVITNQVVAQVDGAAMFAADPKKPIGGNI IAHASTTRL 301 YLRKGRGETRICKIYDSPCLPEAEAMFAINADGVGDAKD*

Fig. 2. The full-length canine Brca2 and Rad51 amino acid sequences. (A) The deduced amino acid sequence of canine Brca2 (GenBank accession number: AB043895). The region in bold face is exon11, and the eight underlined areas are the BRC repeats. Three sequences in bold italics are the predicted NLSs. (B) Deduced amino acid sequence of canine Rad51 (GenBank accession number: AB043896).

\section{RESULTS}

The full-length canine Brca2 cDNA was cloned in seven fragments, while the Rad51 cDNA was cloned in three, as shown in Fig. 1. The open reading frames encoded by the canine Brca2 and Rad51 cDNA were 3,471 and 339 amino acids long, respectively (Fig. 2).

The canine Brca2 protein is longer than the human and murine proteins by 53 and 143 amino acids, respectively.
The canine Brca2 protein shows 68 and 58\% homology with the human and murine Brca 2 proteins, respectively. At the nucleotide level, homology between the canine and human Brca 2 cDNA is $76 \%$, whereas that between canine and murine cDNA is $59 \%$. Canine Brca2 includes the BRC repeats that are conserved among the species so far reported [1]. In addition, the nuclear localization signals (NLS) identified in the human protein [18] exist in the C-terminal region of the canine protein (Fig. 3). Comparison of our 
A
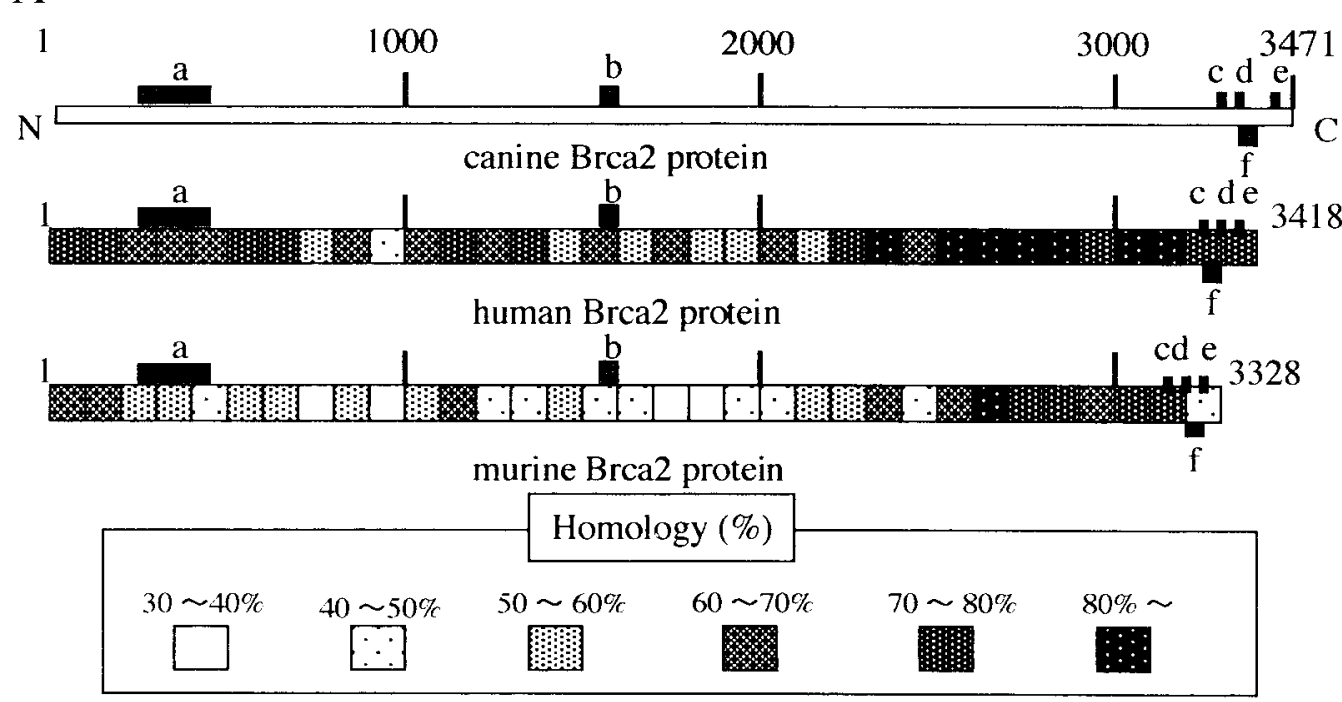

$\mathrm{B}$ a) P/CAF-interacting motif

Canis 299 VLEGEVHEKVLDVSEEEDSFSLCVPKYKTRNLOKIKTSKTRKNIFNETKTSE-CEEAKKQ

Human 290 VLEDEVYETVVDTSEE-DSFSLCFSKCRTKNLQKVRTSKTRKKIFHEANADE-CEKSKNQ

Mouse 277 ILE-D-GETAVDTSEE-DSFSLCFPKRRTRNLQRMRMGKTRKRIFSETRTDELSEEARRQ

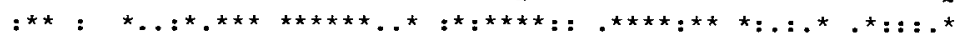

MKENKHSLVSEMEPNDSHPLDWNVTHEKPFGNGTDK I SKE IVLSSASGCSDLTLSSLNGA V-KEKYSFVSEVEPNDTDPLDSNVAHQKPFESGSDKISKEVVPSLACEWSQLTLSGLNGA

T-DDKNSFVFEMEIRESDPLDPGVTSQKPFYSQNEE ICHEAVQCSDSRWSQSNLSGLNET

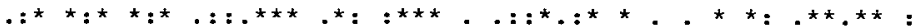

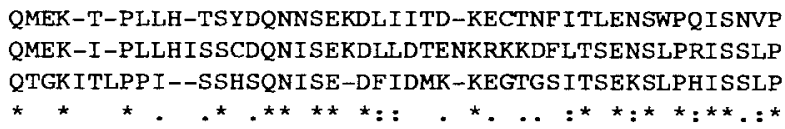

b) BRC repeat5

Canis 1686 TFYTGHGRKISVSEASLFEAKKWLRE

Human 1663 AFYTSCSRKTSVSQTSLLEAKKWLRE

Mouse 1623 AYYTEDSRKTCVRESSISKGRKWLRE

$:: * \star \quad . * * \quad *:: \star \star::: \star \star \star \star \star$

c) NLS 1

d) NLS2

Canis 3303 KTCKKRR Canis 3350 LMKK-EL

Human 3263 KNCKKRR Human 3311 PIKKKEL

Mouse 3186 KTCRKRR Mouse 3234 PIKK-EP

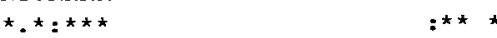

e) NLS 3

Canis 3419 GLKRH

Human 3381 RLKRR

Mouse 3302 QVGPR

f) C-terminal Rad51 binding domain

Canis 3313 FLSRVPLPPSVSPICTFVSPAAQKAFQPPRSCGTKYE

Human 3273 FLSRLPLPPPVSPICTFVSPAAQRAFQPPRSCGTKYE

Mouse 3192 FLSRLPLPSPVSPICTFVSPAAQKAFQPPRSCGTKYA

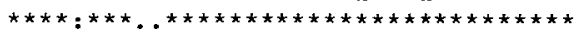

Fig. 3. Comparison of the amino acid sequences of the canine, human, and murine Brca2 proteins. (A) The upper open bar represents canine Brca2 protein, and the solid bars show the homologous regions containing the sequence interacting with p300/CBPassociated factor (P/CAF, a), BRC repeat 5 (b), nuclear localization signals (NLSs, c-e), and C-terminal Rad51 binding domain (f). The middle bar is the human Brca2 protein and the lower one is the murine Brca2 protein. The shaded boxes represent the degree of homology between these proteins, which were divided into 100 amino-acid blocks and compared. (B) Comparison of the functional domains in canine, human, and murine Brca2. The alignment was made using Clustal X. Three characters are used to explain the conserved positions. The characters '*', ':', and '?' indicate conserved positions of single, strong, and weaker groups, respectively (http://www-igbmc.u-strasbg.fr/BioInfo/). 


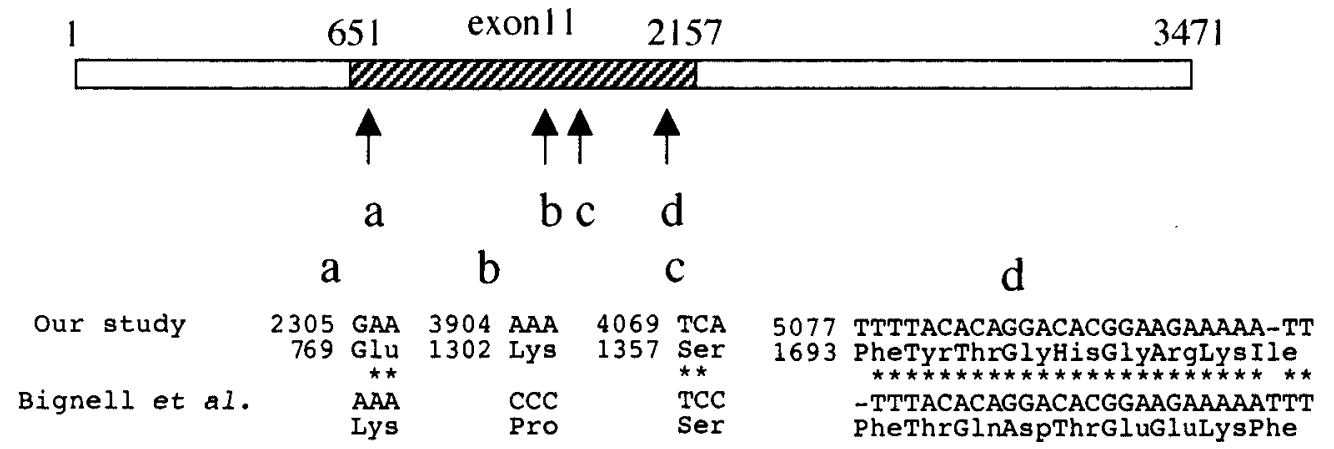

Fig. 4. Polymorphisms in canine Brca2 exon 11. The sequence of canine Brca2 that we cloned was compared with that determined by Bignell et al. (GenBank accession number: Z75664).

cDNA sequence with the partial genomic sequence reported by Bignell et al. [1] identified several nuclear polymorphisms in exon 11. These involve the following nucleotide substitutions: 2,305 A to G, 3,904-3,906 CCC to AAA, 4,071 C to A, 5,077 insert T, and 5,102 delete T. Some of these result in amino acid substitutions (Fig. 4). In contrast to Brca2, the canine Rad51 protein has extremely high homology $(99 \%)$ with the human and mouse proteins.

The tissue distribution of canine Brca2 and Rad51 mRNA was investigated by RT-PCR, using RNA from testis, ovary, mammary gland, spleen, skeletal muscle, and brain. As previously reported in human and mouse [3, 14, 16, 19], Brca2 and Rad51 mRNA were expressed in mammary gland, testis, ovary, and brain (Fig. 5).

\section{DISCUSSION}

We cloned and sequenced the full-length cDNA of canine Brca2 and Rad51. Although Bignell et al. partially sequenced exon 11 of canine Brca2 in a pioneering work[1], no information is available concerning its cDNA. Since human Brca2 mutations that cause mammary tumor exist in the stretch of overall sequence (http://archive.uwcm.ac.uk/ $\mathrm{uwcm} / \mathrm{mg} / \mathrm{ns} / 1 / 387848 . \mathrm{html}$ ), it seems necessary to obtain the entire sequence of canine Brca2. Thus, we amplified the full-length canine Brca2 and Rad51 cDNA by RT-PCR. This should permit the genetic analysis of breast cancer and analysis of the relationships between these genes, to determine whether mutations of these genes in canines are also responsible for a predisposition to mammary tumors.

The overall amino acid sequence homology of Brca2 proteins, $68 \%$ between canine and human and $58 \%$ between canine and mouse, is lower than values reported for other mammalian tumor suppressor genes, such as $p 53, R B 1$ and $A P C$, which show over $80 \%$ homology $[3,16]$. However, this degree of homology is similar to values reported previously for mouse and human Brca 2 proteins. Thus, the degree of homology is sufficient to deem that the clone obtained in this study is canine Brca2. In fact, we have not produced any other homologous clones using our cloning procedure. In spite of the low overall homology of Brca2,

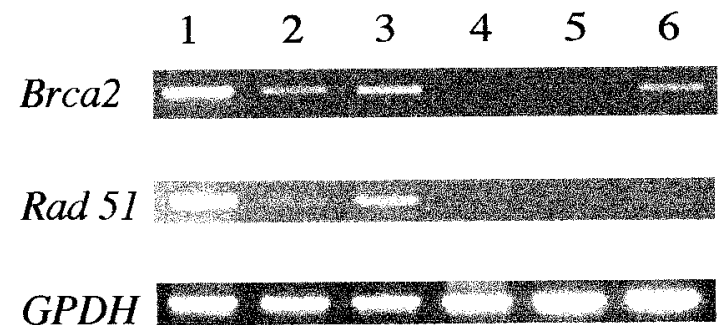

Fig. 5. Expression of canine Brca2 and Rad51. Total RNA from various tissues from an adult beagle was used for RTPCR. Lane 1: testis, lane 2: ovary, lane 3: mammary gland, lane 4: spleen, lane 5: skeletal muscle, and lane 6: brain. GPDH was used as a control.

we can recognize highly homologous regions. Such evolutionarily conserved regions are expected to be of functional importance. A region in the $\mathrm{N}$-terminus that interacts with a transcriptional co-activator protein $\mathrm{p} 300 / \mathrm{CBP}$-associated factor $(\mathrm{P} / \mathrm{CAF})$ is highly conserved in the canine sequence $[6,10]$. In the middle region corresponding to exon 11 , we confirmed the presence of BRC repeats that participate in the interaction between Brca2 and Rad51, as revealed in a human study [21]. Another homologous region is part of the $\mathrm{C}$-terminal region that was also identified to interact with Rad51 in the mouse [11, 17]. Additionally, the C-terminal region also includes the NLSs [18]. Of the three NLSs identified in human Brca2, NLS1 is well conserved, but NLS2 and 3 are not as well conserved. These results support the previous findings that NLS1 is the most important for the appropriate localization of Brca2 protein [18]. In addition to these domains, there should be some functional domains in the $\mathrm{C}$-terminus, because observed subregions in this area show homology exceeding $80 \%$. Alternatively, it is possible that the regions with low homology are responsible for canine specific function of Brca2. However, we could not recognize any motifs or putative functional domains specific for canine Brca2. Further experimental researches are required to examine this possibility.

Comparison of our sequence with that by Bignell et al. 
[1] suggests the existence of nucleotide polymorphisms in canine Brca2. Some of these contribute to amino acid polymorphisms. It is intriguing that one polymorphism alters $\mathrm{BRC}$ repeat 5, which is important for the interaction of human Brca2 with Rad51 [21].

In contrast to Brca2, the canine Rad51 protein has extremely high homology (99\%) with the human and mouse proteins. Rad51 is a homologue of Escherichia coli recombination protein RecA [13], and the conservation of the sequence indicates its importance throughout evolution [14].

Analysis of the expression pattern of the canine Brca2 and Rad51 genes revealed that, like the human [19] and mouse [3] genes, the canine genes are widely transcribed. Both are also expressed in the testis, ovary and brain. The expression of both genes in the mammary gland suggests that these two molecules interact in the canine mammary gland.

In summary, we cloned and sequenced the full-length cDNA of canine Brca2 and Rad51 to provide a basis for study of their relationship to the onset of mammary tumors.

ACKNOWLEDGMENTS. We are grateful to Mr. Richard Turner for critical reading of the manuscript. This work was supported in part by Grants-In-Aid for Scientific Research from the Ministry of Education, Culture, Sports, Science, and Technology of Japan.

\section{REFERENCES}

1. Bignell, G., Stratton, M. R., Ashworth, A. and Wooster, R. 1997. The BRC repeats are conserved in mammalian BRCA2 proteins. Hum. Mol. Genet. 6: 53-58.

2. Chomczynski, P. and Sacchi, N. 1987. Single-step method of RNA isolation by acid guanidinium thiocyanate-phenol-chloroform extraction. Anal.Biochem. 1: 156-159.

3. Connor, F., Smith, A., Wooster, R., Stratton, M., Dixon, A., Campbell, E., Tait, T. M., Freeman, T. and Ashworth, A. 1997. Cloning, chromosomal mapping and expression pattern of the mouse Brca2 gene. Hum. Mol. Genet. 6: 291-300.

4. Dorn, C. R., Taylor, D. O., Schneider, R., Hibbard, H. H. and Klauber, M. R. 1968. Survey of animal neoplasms in Alameda and Contra Costa Counties, California. II. Cancer morbidity in dogs and cats from Alameda County. J. Natl. Cancer Inst. 40: 307-318.

5. Fidler, I. J. and Brodey, R. S. 1967. A necropsy study of canine malignant mammary neoplasms. J. Am. Vet. Med. Assoc. 151: 710-715.

6. Fuks, F., Milner, J. and Kouzarides, T. 1998. BRCA2 associates with acetyltransferase activity when bound to P/CAF. Oncogene 17: 2531-2534.

7. Gayther, S. A., de Foy, K. A., Harrington, P., Pharoah, P., Dunsmuir, W. D., Edwards, S. M., Gillett, C., Ardern-Jones, A., Dearnaley, D. P., Easton, D. F., Ford, D., Shearer, R. J., Kirby, R. S., Dowe, A.L., Kelly, J., Stratton, M. R., Ponder, B. A., Barnes, D. and Eeles, R. A. 2000. The frequency of germ-line mutations in the breast cancer predisposition genes BRCA1 and BRCA2 in familial prostate cancer. The Cancer Research
Campaign. Cancer Res. 60: 4513-4518.

8. Kato, M., Yano, K., Matsuo, F., Saito, H., Katagiri,T., Kurumizaka, H., Yoshimoto, M., Kasumi, F., Akiyama, F., Sakamoto, G., Nagawa, H., Nakamura, Y.and Miki, Y. 2000. Identification of Rad51 alteration in patients with bilateral breast cancer. J. Hum. Genet. 45: 133-137.

9. Kollias, J., Man, S., Marafie, M., Carpenter, K., Pinder, S., Ellis, I. O., Blamey, R. W., Cross, G. and Brook, J. D. 2000. Loss of heterozygosity in bilateral breast cancer. Breast Cancer Res. 64: 241-251.

10. Milner, J., Ponder, B., Hughes-Davies, L., Seltmann, M.and Kouzarides, T. 1997. Transcriptional activation functions in BRCA2. Nature (Lond.) 386: 772-773.

11. Morimatsu, M., Donoho, G. and Hasty, P. 1998. Cells deleted for Brca2 $\mathrm{COOH}$ terminus exhibit hypersensitivity to $\gamma$-radiation and premature senescence. Cancer Res. 58: 3441-3447.

12. Moulton, J. E., Dorn, C. R. and Andersen, A. C. 1970. Canine mammary tumors. Vet. Pathol. 7: 289-320.

13. Ogawa, T., Shinohara, A.and Egelman, E. H. 1993. Similarity of the yeast RAD51 filament to the bacterial RecA filament. Science 259: 1896-1899.

14. Ogawa, T., Nabetani, A., Ikeya, T., Yu, X., Egelman, E. H. and Ogawa, H. 1993. RecA-like recombination proteins in eukaryotes: functions and structures of RAD51 genes. Cold. Spring. Harb. Symp. Quant. Biol. 58: 567-576.

15. Priester, W. A. and Mantel, N. 1971. Occurrence of tumors in domestic animals. Data from 12 United States and Canadian colleges of veterinary medicine. J. Natl. Cancer Inst. 47: 13331344.

16. Sharan, S. K. and Bradley, A. 1997. Murine Brca2: sequence, map position, and expression pattern. Genomics 40: 234-241.

17. Sharan, S. K., Morimatsu, M., Albrecht, U., Lim, D. S., Regel, E., Dinh, C., Sands, A., Eichele, G., Hasty, P. and Bradley, A. 1997. Embryonic lethality and radiation hypersensitivity mediated by Rad51 in mice lacking Brca2. Nature (Lond.) 386: 804-810.

18. Spain, B. H., Larson, C. J., Shihabuddin, L. S., Gage, F. H. and Verma, I. M. 1999. Truncated BRCA2 is cytoplasmic: implications for cancer-linked mutations. Proc. Natl. Acad. Sci. U.S.A. 96: $13920-13925$.

19. Tavtigian, S. V., Simard, J., Rommens, J., Couch, F., ShattuckEidens, D., Neuhausen, S., Merajver, S., Thorlacius, S., Offit, K., Stoppa-Lyonnet, D. et al. 1996. The complete BRCA2 gene and mutations in chromosome 13q-linked kindreds. Nature Genet. 12: 333-337.

20. Taylor, G. N., Shabestari, L., Williams, J., Mays, C. W., Angus, W. and McFarland, S. 1976. Mammary neoplasia in a closed beagle colony. Cancer Res. 36: 2740-2743.

21. Wong, A. K., Pero, R., Ormonde, P. A., Tavtigian, S. V. and Bartel, P. L. 1997. RAD51 interacts with the evolutionarily conserved BRC motifs in the human breast cancer susceptibility gene brca2. J. Biol. Chem. 272: 31941-31944.

22. Wooster, R., Bignell, G., Lancaster, J., Swift, S., Seal, S., Mangion, J., Collins, N., Gregory, S., Gumbs, C. and Micklem, G. 1995. Identification of the breast cancer susceptibility gene BRCA2. Nature (Lond.) 378: 789-792.

23. Wooster, R., Neuhausen, S. L., Mangion, J., Quirk, Y., Ford, D., Collins, N., Nguyen, K., Seal, S., Tran, T., Averill, D. et al. 1994. Localization of a breast cancer susceptibility gene, BRCA2, to chromosome 13q12-13. Science 265: 2088-2090. 